\title{
Workplace Accident Prevalence and Associated Factors among Tobacco Farm in São Lourenço do Sul-RS, Brazil
}

\author{
Prevalência e Fatores Associados à Acidente de Trabalho \\ em Fumicultores do Município de São Lourenço do Sul, RS, Brasil
}

Adriana Marchon Zago ${ }^{1}$ Rodrigo Dalke Meucci ${ }^{2}$ Nadia Fiori ${ }^{3}$ Maria Laura Vidal Carret ${ }^{3}$ Neice Muller Xavier Faria ${ }^{4}$ Anaclaudia Gastal Fassa ${ }^{3}$
${ }^{1}$ Universidade Federal de Pelotas. Marechal Deodoro $1160 / 3^{\circ}$, Centro. 96020 220 Pelotas RS Brasil. adrianamzago@gmail.com ${ }^{2}$ Programa de Saúde Pública, Universidade Federal do Rio Grande. Rio Grande RS Brasil.

${ }^{3}$ Departamento de Medicina Social, Universidade Federal de Pelotas. Pelotas RS Brasil. ${ }^{4}$ Secretaria de Saúde, Prefeitura Municipal de Bento Gonçalves. Bento Gonçalves RS Brasil.
Abstract Agriculture has the highest risk of accidents. In Brazil the reality of this situation is unknown owing to scarcity of studies and underreporting of workplace accidents in rural areas. This article aims to evaluate workplace accident prevalence and associated factors among tobacco farm in Sao Lourenco do Sul-RS, Brazil. Cross-sectional study with 488 tobacco farmers, assessing sociodemographic, behavioural, labour characteristics and association with workplace accidents occurring in their lifetime. The injury prevalence was 24\%. Being male (PR 1.62; 95\%CI 1.04-2.52), and tenant farmer (PR 1.87; 95\%CI 1.29-2.72), bundling tobacco leaves (PR 2.00; 95\%CI 1.143.52) and having minor psychiatric disorders (PR 1.58; 95\%CI 1.06-2.35) were positively associated with accidents. $46 \%$ of serious injuries caused superficial lesions and $26 \%$ caused fractures. Rural workplace accident prevention policies need to be established, particularly for tobacco farming. Larger studies are needed to understand work process-related aspects that increase the risk of accidents.

Key words Workplace accident, Occupational risks, Tobacco, Farm workers, Brazil
Resumo A Agricultura concentra maior risco de acidentes ocupacionais, entretanto sua dimensão é desconhecida pela escassez de estudos brasileiros e subnotificação na área rural. O objetivo deste artigo é avaliar a prevalência e os fatores associados aos acidentes de trabalho em fumicultores em São Lourenço Sul-RS. Estudo transversal com amostra representativa de 488 fumicultores, avaliando características sociodemográficas, comportamentais, atividades laborais e associação com acidentes de trabalho na vida. Prevalência de acidentes na vida foi de $24 \%$, encontrada associação positiva com sexo masculino (RP1,62IC-95\%1,04-2,52), ser arrendatário (RP1,87IC-95\%1,29-2,72), realização manocas (RP2,00IC-95\%1,14-3,52) e problemas psiquiátricos menores ( $R P$ 1,58 IC95\%1,06-2,35). Dentre os acidentes graves, 46\% foram superficiais e $26 \%$, fraturas. Necessário implementar politicas preventivas de acidentes laborais na área rural e, em particular, na fumicultura brasileira; avançar na busca da compreensão dos aspectos relacionados ao processo de trabalho impactantes ao risco de acidentes.

Palavras-chave Acidente de trabalho, Riscos ocupacionais, Tabaco, Trabalhadores rurais, Brasil 


\section{Introduction}

Agricultural activities were responsible for 170,000 deaths per annum from workplace accidents, which represent about $50 \%$ of the global estimates deaths related to all productive activities $^{1,2}$. In some developed countries agriculture fatal workplace accident rate varied between 25 to 30 per 100,000 workers in United States ${ }^{3}$, Russia $^{4}$ and France ${ }^{5}$. In developing countries the statistics are scarce and imprecise, however differences in the proportion of family farming vs corporate farming, in the work process, particularly mechanization, as well as, differences in the main cultures may influence workplace accident rates.

Regarding nonfatal workplace accidents, the variability in the severity and time considered also limits the comparability of rates among different studies worldwide ${ }^{2}$. This difficulty is evident when we observe data from population based studies which point annual prevalence of nonfatal farm accidents of 5\% in India ${ }^{6}, 3.2 \%$ in $\mathrm{Korea}^{7}, 4.5 \%$ in Canada over three years ${ }^{8}$. While data form official registers, which are restricted to more severe injuries, as those which require work leave, point incidence of nonfatal farm accidents in United States of 13 injuries per 1,000 workers in $2004^{9}, 19.4$ injuries per 1,000 workers in crop production in $2014^{3}$ and in Asia incidences varying between 6 and 13 per 1,000 workers ${ }^{10-12}$. In any case the numbers point to an outcome that due to its frequency, severity and social cost is a very important public health problem. This is reinforced by the fact that among all the productive sectors, agriculture has the highest risk of fatal and nonfatal accidents and this situation has not changed in the last decades ${ }^{1,4,5,10,13,14}$.

In Brazil farm workers accounted for 5\% of the 653,000 workplace accidents reported in $2007^{15}$. Studies conducted in the country's southern region found annual workplace farm accidents prevalence of 10 and $11 \% \%^{16,17}$. However, underreporting of accidents prevents more detailed knowledge of this reality ${ }^{18}$. Study conducted in Southern Brazil, Faria et al. found that $91 \%$ of rural workplace accidents had not been officially reported ${ }^{19}$.

Agricultural workplace accidents are two to three times more frequent among males ${ }^{20,21}$. In the United States and Australia, accidents caused by machinery and tractors are among the most frequent ${ }^{21-24}$ and are made worse by machinery lacking protective equipment ${ }^{24}$. In Finland, of nonfatal accidents were caused by animals and $7 \%$ by machinery ${ }^{20}$. In the United States and
Canada, falls and injuries were caused by farming implements accounted for half of nonfatal accidents, followed by injuries were caused by animals ${ }^{8,9}$. In Brazil, within the context of family farming, 56\% of accidents were caused by manual tools and animals ${ }^{16}$. However, it was not found studies addressing accidents among tobacco farmers.

Tobacco growing is a family farming activity of great economic importance in Brazil and the country's southern region concentrates some $95 \%$ of national production ${ }^{25,26}$. Tobacco growing involves more than 200,000 families in mainly manual activities with long working days. This study aims to evaluate work accident prevalence and associated risk factors among tobacco farmers in the southern region of Brazil.

\section{Methods}

A cross-sectional study among tobacco farmers was conducted in the municipality of São Lourenço do Sul (SLS)-RS, Brazil in October and November 2010. A sample of tobacco farmers was selected based on a list of the 3,852 invoices issued for tobacco sales in 2009. The list was provided by SLS Municipal Finance Department. In order to obtain approximately 1,000 farm properties in the municipality, 1,100 invoices were selected randomly. In the first and second stage of the project were included all the properties located in the districts of SLS Canta Galo and Santa Inês. These districts produced the highest volume of tobacco in the municipality. In these stages, in each property, tobacco farmers of all ages were considered to be eligible, provided they worked for at least 15 hours a week doing tobacco farming activities and had applied pesticides in the last year.

The first stage of the project were conducted during the plantation period, and 513 farmers were interviewed, the second stage, were during the leaves growth period and 492 individuals were reevaluated, representing $4 \%$ of losses and refusals. The third stage occurred during harvest period. In this opportunity 2,570 tobacco farmers, including those covered in the first and second stage, were studied. This stage included all districts and the subjects who worked in tobacco farming activities independently of having applied pesticides. The workplace accidents were characterized in the second stage $e^{27,28}$.

For this analysis the 488 individuals aged 18 or over were selected, this being sufficient for the 
study of workplace accident prevalence and associated factors based on the following parameters: a) prevalence study: $95 \%$ confidence interval, estimated workplace accident prevalence of $25 \%$, acceptable margin of error of 5 percentage points and $10 \%$ for losses and refusals; b) associated factors: $95 \%$ confidence interval, minimum statistical power of $80 \%$, relative risk of 2.0 , exposed/not exposed ratio varying between 1:1 and 4:1, plus $15 \%$ for the adjustment of confounding factors.

Data was collected at the Primary Healthcare Centre by selected and trained interviewers and doctors specifically trained for this study performed the medical assessment. The following information was investigated: demographic information (sex, age, marital status, schooling and age at which started tobacco farming), labour relations (property owners or tenant farmers); economic status was assessed using information about the farm property (area of the property, annual tobacco production and expenditure on vehicle tax- "IPVA"), presence of other crops and ownership of animals, farm implements and tractors.

Consumption of alcoholic beverages was characterized according to the number of units consumed on weekdays and weekends (one unit corresponding to a can of beer, a glass of wine or a measure of spirits). Heavy drinker was considered to be women who consume more than 7 drinks a week and men who consume more than 14 drinks a week. Smoking was categorized into non-smokers, former smokers (stopped smoking more than a month ago) and smokers (one or more cigarettes day for more than one month) ${ }^{29}$.

Exposed individuals were considered to be those who replied that they always or frequently did specific tobacco farming activities relating to planting, harvesting and tobacco leaf curing. Unexposed individuals were considered to be those who replied no or sometimes. Information about the number of hours worked per day doing farming and non-farming activities, physical exertion and work intensity referred to the harvest period. Pesticide poisoning was defined as having had symptoms of poisoning at some point in life. Psychiatric disorders, anxiety and depression were assessed by the doctors.

The rural workplace accident over lifetime outcome was characterized by the question "Have you ever had a rural workplace accident in your lifetime?" Interviewees were then asked how long ago their most serious accident had occurred, the type of injury caused and if there had been sequelae.
For the purposes of the descriptive analysis, the numerical variables (age, schooling, tobacco production, age at which started tobacco farming, daily working hours) were categorized. Outcome prevalence was then calculated according to the independent variables. The crude and adjusted analyses of the associations between the independent variables and the outcome were performed using Poisson regression with robust variance and backward selection. Wald's heterogeneity test and Wald's linear trend test were used. The multivariate analysis followed the hierarchical model, whereby the sociodemographic and economic characteristics were included on the first level, behavioural characteristics on the second level, whilst the variables relating to age at which started tobacco farming, labour relations and daily working hours were included on the third level. Tobacco farming tasks and workloads were included on the fourth level and comorbidities were assessed on the final level. Variables with $\mathrm{p}<=0.20$ were kept in the model and those with $\mathrm{p}<0.05$ were considered to be associated with the outcome. The analyses were performed using Stata $13^{\circ}$.

The study was submitted to and approved by the Federal University of Pelotas Research Ethics Committee. All participants voluntarily signed the consent form and the right to refuse and the right to the confidentiality of the information collected were ensured. All individuals identified as having health problems were referred to health services for free care.

\section{Results}

From the 488 tobacco farmers studied, $76.2 \%$ were male and a similar proportion was found in the $18-50$ age strata ( $25 \%$ per stratum). With regard to schooling, $42 \%$ had studied for 5 to 7 years and $73 \%$ were married. High-risk alcohol consumption was referred by $26.7 \%$ and smoking by $21 \%$ of tobacco farmers (Table 1 ). About $60 \%$ of interviewees started working in farming before they were 13 years old and 38\% began working with tobacco cultivation before they were 15 . Some $60 \%$ worked on small farm properties with up to 5 hectares of land. Half the tobacco farmers had produced 5 to 10 tonnes of tobacco in the previous year and $40 \%$ of interviewees spent between BRL 500 and BRL 1000 per annum on vehicle tax - IPVA (Table 1).

Almost all the interviewees (90\%) were the owners of the lands they farmed and $44 \%$ worked 
more than ten hours a day, whilst $12 \%$ worked less than seven hours a day. With regard to the various activities carried out as part of tobacco farming, 95\% worked on preparing the ground

Table 1. Sociodemographic and behavioural characteristics of tobacco farmers applying pesticides in the last year.

\begin{tabular}{|c|c|c|}
\hline \multirow[t]{2}{*}{ Variable } & \multicolumn{2}{|c|}{$\begin{array}{l}\text { Tobacco } \\
\text { farmers } \\
(\mathrm{N}=488)\end{array}$} \\
\hline & $\mathbf{N}$ & $\%$ \\
\hline \multicolumn{3}{|l|}{ Sociodemographic } \\
\hline \multicolumn{3}{|l|}{ Sex } \\
\hline Male & 372 & 76.2 \\
\hline Female & 116 & 23.8 \\
\hline \multicolumn{3}{|l|}{ Age } \\
\hline $18-29$ years & 124 & 25.4 \\
\hline $30-38$ years & 125 & 25.6 \\
\hline $39-50$ years & 126 & 25.8 \\
\hline 51 years and over & 113 & 23.2 \\
\hline \multicolumn{3}{|l|}{ Marital status } \\
\hline Married/partner & 347 & 73.2 \\
\hline Single/widowed/separated & 127 & 26.8 \\
\hline \multicolumn{3}{|l|}{ Schooling } \\
\hline up to 4 years & 217 & 44.5 \\
\hline 5- 7 years & 208 & 42.6 \\
\hline$\geq 8$ years & 63 & 12.9 \\
\hline \multicolumn{3}{|l|}{ Tobacco cultivation per hectare } \\
\hline 1-5 hectares & 277 & 58.7 \\
\hline 6-20 hectares & 164 & 34.7 \\
\hline$>21$ hectares & 31 & 6.6 \\
\hline \multicolumn{3}{|c|}{ Annual tobacco production $(\mathrm{Kg})$} \\
\hline up to 5000 & 130 & 27.6 \\
\hline $5001-10000$ & 212 & 44.9 \\
\hline $10001-36000$ & 130 & 27.5 \\
\hline \multicolumn{3}{|c|}{ Expenses with Taxation (vehicles) in BRL } \\
\hline Exempt & 26 & 5.6 \\
\hline up to 500 & 128 & 27.6 \\
\hline $501-1000$ & 186 & 40.1 \\
\hline$\geq 1001$ & 124 & 26.7 \\
\hline \multicolumn{3}{|l|}{ Labour relation } \\
\hline Property owner & 437 & 89.5 \\
\hline Tenant farmer & 51 & 10.5 \\
\hline \multicolumn{3}{|l|}{ Behavioural Aspects } \\
\hline \multicolumn{3}{|l|}{ Heavy drinking } \\
\hline No & 344 & 80.7 \\
\hline Yes & 82 & 19.3 \\
\hline \multicolumn{3}{|l|}{ Smoking } \\
\hline No & 288 & 60.8 \\
\hline Former smoker & 82 & 17.3 \\
\hline Smoker & 104 & 21.9 \\
\hline
\end{tabular}

and harvesting, $85 \%$ classified and bundled tobacco leaves, $60 \%$ climbed up scaffolding in curing barns, controlled the kilns, cut trees and drove tractors and $49 \%$ put tobacco leaves onto tobacco sticks.

Among of 488 interviewees, $24.4 \%$ had suffered a workplace accident in their lifetime (27\% males and $16 \%$ females), not counting pesticide poisoning. Pesticide poisoning over lifetime was reported by $9.6 \%$ of interviewees (Table 2 ).

In the adjusted analysis males were $62 \%$ more at risk of workplace accidents over lifetime than females, but no association was found between workplace accidents and age, marital status or schooling. Among the economic markers evaluated, those who were exempt from vehicle tax

Table 2. Job characteristics of tobacco farmers applying pesticides in the last year.

\begin{tabular}{|c|c|c|}
\hline \multirow[t]{2}{*}{ Variable } & \multicolumn{2}{|c|}{$\begin{array}{c}\text { Tobacco } \\
\text { farmers } \\
(\mathrm{N}=\mathbf{4 8 8}) \\
\end{array}$} \\
\hline & $\mathbf{N}$ & $\%$ \\
\hline \multicolumn{3}{|c|}{ Age at which began tobacco farming } \\
\hline$\leq 15$ years & 181 & 38.2 \\
\hline $16-21$ years & 165 & 34.8 \\
\hline$\geq 22$ years & 128 & 27.0 \\
\hline \multicolumn{3}{|l|}{ Total daily working hours } \\
\hline$\leq 9$ hours & 260 & 54.1 \\
\hline$\geq 10$ hours & 215 & 45.9 \\
\hline \multicolumn{3}{|l|}{ Bundling tobacco leaves } \\
\hline No & 82 & 17.3 \\
\hline Yes & 392 & 82.7 \\
\hline \multicolumn{3}{|l|}{ Driving tractor } \\
\hline No & 168 & 35.4 \\
\hline Yes & 306 & 64.6 \\
\hline \multicolumn{3}{|l|}{ Heavy physical exertion } \\
\hline No & 189 & 38.7 \\
\hline Yes & 299 & 61.3 \\
\hline \multicolumn{3}{|l|}{ Working under pressure } \\
\hline No & 274 & 56.2 \\
\hline Yes & 214 & 43.8 \\
\hline \multicolumn{3}{|l|}{ Intense work } \\
\hline No & 56 & 11.8 \\
\hline Yes & 418 & 88.2 \\
\hline \multicolumn{3}{|l|}{ Anxiety/depression } \\
\hline No & 355 & 73.3 \\
\hline Yes & 129 & 26.7 \\
\hline \multicolumn{3}{|l|}{ Workplace accident } \\
\hline Lifetime & 120 & 24.6 \\
\hline In the last 5 years * & 56 & 11.4 \\
\hline
\end{tabular}

${ }^{*}$ Most serious workplace accidents in the last 5 years. 
(IPVA) were $84 \%$ more at risk of accidents compared to those who spent more than BRL 500 per annum on vehicle tax. Tenant farmers (PR 2.04; 95\%CI 1.43- 2.90) and farmers who bundled tobacco leaves (PR 1.85; 95\%CI 1.06-3.24) had around twice as many workplace accidents than farm owners and those who did not do this job, respectively. Individuals with depression and anxiety were 50\% more at risk (PR 1.50; 95\%CI 1.08-2.08). No association with workplace accidents was found in relation to working more than ten hours a day or greater physical exertion, neither with driving tractors (after adjustment) (Table 3).

Table 3. Prevalence and factors associated with workplace accidents over lifetime among tobacco farmers applying pesticides in the last year $(\mathrm{N}=488)$.

\begin{tabular}{|c|c|c|c|c|c|c|c|c|}
\hline \multirow{2}{*}{ Variable } & \multirow[b]{2}{*}{$\mathbf{N}$} & \multirow[b]{2}{*}{$\mathbf{P}$} & \multicolumn{3}{|c|}{ Crude Analysis } & \multicolumn{3}{|c|}{ Adjusted Analysis* } \\
\hline & & & PR & 95\%CI & $\mathbf{p}$ & PR & 95\%CI & $\mathrm{p}$ \\
\hline \multicolumn{9}{|l|}{ First Level } \\
\hline Sex & & & & & 0.025 & & & 0.023 \\
\hline Female & 116 & 16.4 & 1 & - & & 1 & - & \\
\hline Male & 371 & 27.2 & 1.66 & $(1.06-2.59)$ & & 1.66 & $(1.07-2.59)$ & \\
\hline Schooling & & & & & 0.152 & & & 0.089 \\
\hline Up to 4 years & 216 & 27.8 & 1 & - & & 1 & - & \\
\hline$\geq 5$ years & 271 & 22.1 & 0.79 & $(0.58-1.09)$ & & 0.77 & $(0.56-1.06)$ & \\
\hline \multicolumn{9}{|l|}{ Expenses with IPVA } \\
\hline Exempt & 26 & 46.1 & 1.85 & $(1.17-2.93)$ & 0.008 & 1.84 & $(1.16-2.91)$ & 0.009 \\
\hline Up to 500 & 127 & 20.5 & 0.82 & $(0.55-1.22)$ & 0.328 & 0.81 & $(0.55-1.20)$ & 0.307 \\
\hline$\geq 501$ & 309 & 24.9 & 1 & - & & 1 & - & \\
\hline \multicolumn{9}{|l|}{ Second Level } \\
\hline \multicolumn{9}{|c|}{ High-risk alcohol consumption/week } \\
\hline No & & & & & 0.135 & & & 0.42 \\
\hline \multirow[t]{2}{*}{ Yes } & 339 & 23.9 & 1 & - & & 1 & - & \\
\hline & 82 & 31.7 & 1.33 & $(0.92-1.92)$ & & 1.17 & $(0.79-1.73)$ & \\
\hline \multicolumn{9}{|l|}{ Third Level } \\
\hline Labour relations & & & & & 0.000 & & & 0.000 \\
\hline Property owner & 436 & 22.5 & 1 & - & & 1 & - & \\
\hline Tenant farmer & 51 & 45.1 & 2.03 & $(1.43-2.88)$ & & 2.04 & $(1.43-2.90)$ & \\
\hline Daily working hours & & & & & 0.020 & & & 0.112 \\
\hline Up to 9 hours & 272 & 20.6 & 1 & - & & 1 & - & \\
\hline$\geq 10$ hours & 215 & 29.7 & 1.44 & $(1.06-1.97)$ & & 1.33 & $(0.97-1.83)$ & \\
\hline \multicolumn{9}{|l|}{ Fourth Level } \\
\hline Bundling tobacco leaves & & & & & 0.019 & & & 0.030 \\
\hline No & 82 & 13.4 & 1 & - & & 1 & - & \\
\hline Yes & 390 & 26.7 & 1.99 & $(1.12-3.54)$ & & 1.85 & $(1.06-3.24)$ & \\
\hline Driving tractor & & & & & 0.031 & & & 0.123 \\
\hline No & 168 & 18.4 & 1 & - & & 1 & - & \\
\hline Yes & 304 & 27.6 & 1.50 & $(1.03-2.16)$ & & 1.39 & $(0.91-2.10)$ & \\
\hline Heavy physical exertion & & & & & 0.026 & & & 0.189 \\
\hline No & 189 & 19.0 & 1 & - & & 1 & - & \\
\hline Yes & 298 & 28.2 & 1.47 & $(1.04-2.09)$ & & 1.30 & $(0.89-1.79)$ & \\
\hline Intense work & & & & & 0.146 & & & 0.192 \\
\hline No & 56 & 16.1 & 1 & - & & 1 & - & \\
\hline Yes & 416 & 25.4 & 1.58 & $(0.85-2.95)$ & & 1.48 & $(0.82-2.70)$ & \\
\hline \multicolumn{9}{|l|}{ Fifth Level } \\
\hline Depression/anxiety & & & & & 0.013 & & & 0.014 \\
\hline No & 412 & 22.6 & 1 & - & & 1 & - & \\
\hline Yes & 54 & 37.0 & 1.64 & $(1.11-2.43)$ & & 1.50 & $(1.08-2.08)$ & \\
\hline
\end{tabular}

N: Total sample size. P: Prevalence. RP: Prevalence ratio. 95\%CI: 95\% confidence interval. P: $p$ value of Wald's heterogeneity test. SRQ: Self-Reporting Questionnaire. * The variables are adjusted to those on the same level and those on the level above. 
Among tobacco farmers who had suffered accidents, the most serious accident occurred before 16 years of age in $11 \%$ of cases and $47 \%$ had occurred less than five years previously. The most frequent types of injury were cuts/contusions and fractures, $45 \%$ and $26 \%$, respectively. Sequelae were followed in $30 \%$ of accidents and amputation (fingers) occurred in $8 \%$. Loss of movement, generally in the fingers, occurred in $12 \%$ and blindness due to eye trauma was reported by $3.8 \%$ of those who suffered accidents (Table 4).

\section{Discussion}

The study shows high prevalence of nonfatal workplace accidents over lifetime among the tobacco farmers. The fact that accidents over lifetime were considered makes comparison with other studies difficult. On the other hand, when considering the occurrence of the most serious accidents in the last five years, prevalence is higher $(4.5 \%)$ than that found in Canada, although this prevalence was not restricted to the most serious

Table 4. Characteristics of workplace accidents occurring during the lifetime of tobacco farmers applying pesticides in the last year: type of injury and sequelae.

\begin{tabular}{lrr}
\hline \multicolumn{1}{c}{ Variables } & N & $\%$ \\
\hline Age when accident occurred $(\mathrm{N}=120)$ & & \\
$\leq 15$ years & 13 & 11.0 \\
16-21 years & 17 & 14.4 \\
$\geq 22$ years & 88 & 74.6 \\
How long ago accident occurred $(\mathrm{N}=120)$ & & \\
$\leq 1$ year & 17 & 14.4 \\
2-5 years & 39 & 33.1 \\
6-10 years & 31 & 26.3 \\
$\geq 11$ years & 31 & 26.3 \\
Accident injury type $(\mathrm{N}=105)$ & & \\
Cut/puncture/laceration/abrasion & 48 & 45.7 \\
Fracture/dislocation & 28 & 26.7 \\
Amputation & 08 & 7.6 \\
Stinging & 08 & 7.6 \\
Contusion/sprain & 07 & 6.7 \\
Eye trauma & 04 & 3.9 \\
Burn & 01 & 0.9 \\
Multiple traumas & 01 & 0.9 \\
Accident sequelae $(\mathrm{N}=105)$ & & \\
No sequelae & 75 & 71.4 \\
Loss of movement & 13 & 12.4 \\
Amputation & 08 & 7.6 \\
Scar & 05 & 4.8 \\
Loss of sight & 04 & 3.8 \\
\hline
\end{tabular}

accidents ${ }^{8}$. The majority of studies conducted over a longer period of observation assessed accident incidence and this varied between 8 and 13 accidents per 1000 workers in the United States ${ }^{9}$, Malaysia ${ }^{11}$ and India ${ }^{10}$. The greater proportion of men in this study may have contributed to the higher prevalence found, although the type of cultivation and the level of mechanization may also have influenced the occurrence of accidents.

Tobacco cultivation in Brazil is done by family farmers with little mechanization and this requires a larger workforce. The high prevalence found suggests that this type of cultivation may be associated with a greater risk of accidents. In Vietnam tobacco cultivation was associated with risk of disease 3.5 times greater than with cultivation of other crops, and was principally related to exposure to pesticides and nicotine ${ }^{30}$. In Finland, where small-scale cultivation is predominant, $70 \%$ of those who suffered accidents at work and made insurance claims over a 26 year period were farmers, followed by livestock workers. It is relevant to note that characterizing workplace accidents over a person's lifetime can result in prevalence being underestimated because of the long memory recall period, so that interviewees may have only reported more serious accidents.

Higher risk of accidents was found amongst males and this may be related to variability in the intensity and frequency of the work done by males and females. This finding is in agreement with the literature, which indicates risk two to three times greater for males $11,27,28,31$, although it has been demonstrated that women handling tools and animals are $49 \%$ more at risk in Colorado $^{32}$. Diverse studies have found higher risk among individuals aged over 50 years $\mathrm{r}^{6,711,31,33}$. This fact was not found in tobacco farming and perhaps this was influenced by the division of labour according to age, whereby more arduous and risky jobs are delegated to the younger.

The lack of association between schooling and workplace accidents over lifetime is consistent with studies of Canadian farmers ${ }^{8}$ and United States farmers ${ }^{14}$, although in those countries farmers had more schooling. On the other hand, a study in China found that the risk of accidents was $50 \%$ higher among those with less schooling $^{34}$. This divergence may be associated with greater schooling homogeneity in those studies that did not find association.

The tenant farmer employment relationship showed high risk of accidents, twice as high as among landowners. This agrees with findings in Finland $^{31}$ and Australia ${ }^{35}$, although this associa- 
tion was not found in India ${ }^{36}$. The fact of being a tenant farmer may be related to poorer working conditions and being under greater pressure to get jobs done, thus increasing the risk of accidents. Although no association was found between accidents and number of hours worked, which is in agreement with another study conducted in the same region of Brazil ${ }^{16}$, other studies have shown that longer daily working hours, above ten hours a day, increased the risk of accidents by two to three times among workers in the United States $^{8,21,33}$, China ${ }^{34}$. Australia ${ }^{35}$ and Ko$\mathrm{rea}^{7}$. Males have longer working hours and thus the association between daily working hours and accidents lost significance after adjustment for sex. Furthermore, the majority of tobacco farmers have longer daily working hours during the harvest period and even the work of those in the category of less than nine hours is highly concentrated over seven and eight hours, so that there are no marked differences between categories.

With regard to economic status, no association was found with the volume of tobacco production, however exemption from vehicle tax (IPVA), which indicates ownership of old car, was associated with risk of accidents, suggesting that, even among a very homogeneous economic level, those who cannot afford to have a newer vehicle, particularly in the rural area where this good is sometimes essential to commute, have worst health indicators. This was consistent with studies conducted with subsistence crop family farmers in Brazil and lower-income machinery operators in China, which found double the risk of accidents ${ }^{17,30}$. On the other hand, income was not associated with accidents among self-employed farmers growing a variety of crops in Canada, the United States and India ${ }^{8,33,35-37}$ whereas in Finland this association was positive when analysing serious accidents that lead to compensation $^{31}$. Higher economic status may mean greater access to mechanization and technology, thus reducing the risk of accidents. For instance, the use of electric kilns is greater among tobacco farmers of higher economic status and these reduce certain workloads such as working at night during the harvest.

In keeping with the studies conducted in Australia $^{35}$ and California ${ }^{33}$, there was no association between heavy drinking and risk of accident, although in Colorado there was greater risk of accidents among heavy drinkers when compared to the abstemious ${ }^{38}$. In China, Wang et al. ${ }^{39}$ found that the risk of accidents increased progressively according to the number of daily drinks and the weekly frequency of alcoholic drink intake. Lack of perception of risk and reduced ability to respond rapidly to stimuli are considered to be the probable mechanisms for positive association between heavy drinking and accidents at work. However, it may be that within the context of working together as a family, other family members take steps to prevent heavy drinkers of doing more risky activities at work.

With regard to activities specific to tobacco cultivation, only bundling, whereby tobacco leaves are tied into bundles to be fastened onto tobacco sticks for drying in kilns, was associated with risk of accidents over lifetime. This may have occurred owing to reverse causality, especially considering the long memory recall period for the outcome. In this way, workers with limitations might be selected to do jobs requiring less physical exertion. In the adjusted analysis, greater physical exertion was not associated with accidents. This may be related to healthy worker effect bias, especially owing to the long memory recall period. In this case, only healthy workers (having no limitations caused by previous accidents at work) would do jobs requiring physical exertion.

This study found that the presence of depression and anxiety was positively associated with accidents. Previous studies found that situations of stress, debt and family tension were associated with accidents in China ${ }^{27,34}$. These findings may indicate that lower ability to concentrate at work could be caused by these situations and result in risk of accidents. Moreover, depression is associated with pesticide exposure ${ }^{40}$ and might be a marker of neurologic problems resultant of this exposure, which could also increase the risk of accidents. Nevertheless, this association may be due to reverse causality, given that people who suffer accidents, which result in limitations or sequelae, may also be more subject to depression or anxiety.

In industrialized countries or farming involving greater mechanization, the main causes of accidents are falls, tractors, machinery and other equipment ${ }^{11,12,21,41}$. In this study there was a higher proportion of superficial injuries. This is in agreement with the study conducted by Felbergh et al. in which injuries involving cuts/contusions were found in $50 \%$ of those suffering accidents in family farming in Southern Brazil, although that study did not find fractures and amputations ${ }^{17}$. This finding is consistent with the predominantly manual activities undertaken in tobacco farming. The different injury type pattern found in this 
study is probably due to the longer period of observation (lifetime) and the reference to the most serious accidents ${ }^{11,33}$.

A number of limitations need to be considered when interpreting our results. The sample is restricted to tobacco farmers who applied pesticides in last year, therefore includes more males and younger farmers and is not representative of the tobacco farmers' population. However, the studied sample perform all types of activities in the tobacco plantation and give an idea of the accidents profile among those intensely involved in this type of cultivation. The workplace accidents were characterized in a lifetime period, the long memory recall underestimate its frequency and concentrate the report of serious injuries. The healthy workers effect also underestimate the lifetime workplace accidents, because the sample is restricted to workers, and those who suffered accidents, which resulted in limitations or sequelae, might not be working anymore.

\section{Collaborations}

AM Zago worked on the analysis and writing of the article, AG Fassa worked on research design and article revision; RD Meucci worked on research and review of analyzes and methods of the article; N Fiori worked on research; MLV Carret worked on research and NMX Faria worked on article research and discussion.
This study assessed association between demographic, socioeconomic and occupational factors and workplace accidents over lifetime among tobacco farmers who applied pesticides. It is a relevant contribution in view of the dimension of farm work accidents and the large number of families involved in tobacco farming in Southern Brazil. The high prevalence of accidents indicates that policies are needed to prevent tobacco farming accidents. Larger studies are needed to enable more in-depth investigation of the occupational risk factors for accidents at tobacco farming. It is important to describe stage of agricultural cycle, activities, machinery and tools related to work accidents in order to detail the prevention strategies. The farmers should be aware about the risk of accidents and educated to perform the tasks in a safety way, using personal protective equipment when required. Moreover, in some circumstances mechanization and machinery and tools with protection might be effective to prevent accidents.

\section{Acknowledgements}

This study received funding from the National Council for Scientific and Technological Development (CNPq), Coordination for the Improvement of High Education Personnel (CAPES), and from the Rio Grande do Sul Research Support Foundation (FAPERGS). 


\section{References}

1. Bulat P, Somaruga C, Colosio C. Occupational health and safety in agriculture: situation and priorities at the beginning of the third millennium. Med Lav 2006; 97(2):420-429.

2. Takala J, Hämäläinen P, Saarela KL, Yun LY, Manickam K, Jin TW, Heng P, Tjong C, Kheng LG, Lim S, Lin GS. Global Estimates of the Burden of Injury and Illness at Work in 2012. J Occup Environ Hyg 2014; 11(5):326337.

3. US Department of Labour: Bureau of Labour Statistic. Census of Fatal Occupational Injuries. [cited 2016 Aug 4]. Available from: http://wwwblsgov/iif/oshwc/cfoi/ cfch0013pdf

4. Varakina Zh L, Vyazmin AM, Sannikov AL, Nygard $\mathrm{CH}$, Grjibovski AM. Fatal occupational injuries in the Arkhangelsk region, Northwest Russia. Occup Med (Lond) 2010; 60(6):470-475.

5. Briere J, Chevalier A, Imbernon E. Surveillance of fatal occupational injuries in France: 2002-2004. Am J Ind Med 2010; 53(11):1109-1118.

6. Kalaiselvan G, Dongre AR, Mahalakshmy T. Epidemiology of injury in rural Pondicherry, India. J Inj Violence Res. 2011; 3(2):62-7.

7. Chae H, Min K, Youn K, Park J, Kim K, Kim H, Lee K. Estimated rate of agricultural injury: the Korean Farmers' Occupational Disease and Injury Survey. Ann Occup Environ Med 2014; 26(8):1-7.

8. Pickett W, Day AG, Hagel L, Sun X, Day L, Marlenga B, Brison RJ, Pahwa P, Crowe T, Voaklander DC, Dosman J. Socioeconomic status and injury in a cohort of Saskatchewan farmers. J Rural Health 2011; 27(3):245-254.

9. Goldcamp EM. Work-related non-fatal injuries to adults on farms in the U.S., 2001 and 2004. J Agric Saf Health 2010; 16(1):41-51.

10. Das B. Agricultural work related injuries among the farmers of West Bengal, India. Int J Inj Contr Saf Promot 2014; 21(3):205-215.

11. Abas AB, Said AR, Mohammed MA, Sathiakumar N Non-fatal occupational injuries among non-governmental employees in Malaysia. Int J Occup Environ Health 2011; 17(1):38-48.

12. Nag PK Nag A. Drudgery, Accidents and Injuries in Indian Agriculture. Ind Health 2004; 42(2):149-162.

13. Kyung Yong RHEE SWC, Young Sun KIM, Kwon Ho KOO. The Trend of Occupational Injuries in Korea from 2001 to 2010. Saf Health Work 2013; 4(1):63-70.

14. Kachan D, Fleming LE, LeBlanc WG, Goodman E, Arheart KL, Caban-Martinez AJ, Clarke TC, Ocasio MA, Christ S, Lee DJ. Worker populations at risk for work-related injuries across the life course. Am J Ind Med 2012; 55(4):361-366.

15. Brasil. Ministerio da Previdencia Social. Anuário Estatístico da Previdência Social 2007. [acessado 2015 maio 10]. Disponível em: http://wwwl.previdencia. gov.br/aeps2007/16_01_03_01.asp

16. Fehlberg MF, Santos I, Tomasi E. Prevalence and associated factors to rural occupational accidents, Brazil. Rev Saude Publica 2001; 35(3):269-275.

17. Fehlberg F, Santos IS,Tomasi E. Rural work-related accidents in Pelotas, Rio Grande do Sul State, Brazil: a population-based cross-sectional study. Cad Saude Publica 2001; 17(6):1375-1381.
18. Santana VNL, Waldvoge BC. Acidentes de trabalho no Brasil entre 1994 e 2004: uma revisão. Cien Saude Colet 2005; 10(4):841-855.

19. Faria NM, Facchini LA, Fassa AG, Tomasi E. The rural labor process and health in the Southern Brazilian mountains: a descriptive study. Cad Saude Publica 2000; 16(1):115-128.

20. Karttunen JP, Rautiainen RH. Distribution and characteristics of occupational injuries and diseases among farmers: a retrospective analysis of workers' compensation claims. Am J Ind Med 2013; 56(8):856-869.

21. Gerberich SG, Gibson RW, French LR, Lee TY, Carr WP, Kochevar L, Renier CM, Shutske J. Machinery-related injuries: regional rural injury study--I (RRIS--I). Accid Anal Prev 1998; 30(6):793-804.

22. Lee TY, Gerberich SG, Gibson RW, Carr WP, Shutske J, Renier CM. A population-based study of tractor-related injuries: Regional Rural Injury Study-I (RRIS-I). J Occup Environ Med 1996; 38(8):782-793.

23. Layde PM, Nordstrom DL, Stueland D, Brand L, Olson KA. Machine-related occupational injuries in farm residents. Ann Epidemiol 1995; 5(6):419-426.

24. Jones CB, Day L, Staines C. Trends in tractor related fatalities among adults working on farms in Victoria, Australia, 1985-2010. Accid Anal Prev 2013; 50:110-114.

25. Buainain AM. Organização e Funcionamento do Mercado de Tabaco no Sul no Brasil. Campinas: Editora da Unicamp; 2009.

26. Associação dos Fumicultores do Brasil (AFUBRA). [acessado 2014 Out 6]. Disponível em: http://www. afubra.com.br/

27. Zheng L, Zhao N, Chen D, Hu M, Fu X, Stallones L, Xiang H, Wang Z. Nonfatal work-related injuries among agricultural machinery operators in northern China: a cross-sectional study. Injury 2014; 45(3):599604 .

28. Davies H, Koehlmoos TP, Courtice MN, Ahmad SA Occupational injury in rural Bangladesh: data gathering using household survey. Int J Occup Environ Health 2011; 17(3):214-222.

29. US Department of Health and Human Services, U.S Department of Agriculture. 2015; $8^{\text {th }}$ Edition. 2015 - 2020 Dietary Guidelines for Americans. [cited 2014 Oct 6]. Available at: http://healthgov/dietaryguidelines/2015/guidelines/

30. Van Minh H, Giang KB, Bich NN, Huong NT. Tobacco farming in rural Vietnam: questionable economic gain but evident health risks. BMC Public Health 2009; 9:24.

31. Rautiainen RH, Ledolter J, Donham KJ, Ohsfeldt RL, Zwerling C. Risk factors for serious injury in Finnish agriculture. Am J Ind Med 2009; 52(5):419-428.

32. Stallones L, Beseler C. Farm work practices and farm injuries in Colorado. Inj Prev 2003; 9(3):241-244.

33. McCurdy SA, Farrar JA, Beaumont JJ, Samuels SJ, Green RS, Scott LC, Schenker MB. Nonfatal occupational injury among California farm operators. J Agric Saf Health 2004; 10(2):103-119.

34. Xiang H, Wang Z, Stallones L, Keefe TJ, Huang X, Fu $\mathrm{X}$. Agricultural work-related injuries among farmers in Hubei, People's Republic of China. Am J Public Health 2000; 90(8):1269-1276. 
35. Day L, Voaklander D, Sim M, Wolfe R, Langley J, Dosman J, Hagel L, Ozanne-Smith J. Risk factors for work related injury among male farmers. Occup Environ Med 2009; 66(5):312-318.

36. Dandona R, Kumar GA, Ivers R, Joshi R, Neal B, Dandona L. Characteristics of non-fatal fall injuries in rural India. Inj Prev 2010; 16(3):166-171.

37. Sprince NL, Zwerling C, Lynch CF, Whitten PS, Thu K, Gillette PP, Burmeister LF, Alavanja MC. Risk factors for falls among Iowa farmers: a case-control study nested in the Agricultural Health Study. Am J Ind Med 2003; 44(3):265-272.

38. Stallones L, Xiang $\mathrm{H}$. Alcohol consumption patterns and work-related injuries among Colorado farm residents. Am J Prev Med 2003; 25(1):25-30.

39. Wang L, Wheeler K, Bai L, Stallones L, Dong Y, Ge J, Xiang $\mathrm{H}$. Alcohol consumption and work-related injuries among farmers in Heilongjiang Province, People's Republic of China. Am J Ind Med 2010; 53(8):825-835.

40. Faria NM FA, Meucci RD, Fiori NS, Miranda VI. Occupational exposure to pesticides, nicotine and minor psychiatric disorders among tobacco farmers in southern Brazil. Neurotoxicology 2014; 45:347-354.

41. Solomon C, Poole J, Palmer KT, Coggon D. Non-fatal occupational injuries in British agriculture. Occup Environ Med 2007; 64(3):150-154.

Artigo apresentado em 12/11/2015

Aprovado em 25/07/2016

Versão final apresentada em 27/07/2016 